\title{
友田智哲 学位論文審查要旨
}

\author{
主 查 北 野 博 也 \\ 副主査井藤 久 雄 \\ 同重 政千 秋
}

\section{主論文}

Indomethacin inhibits cell growth of medullary thyroid carcinoma by reducing cell cycle progression into $\mathrm{S}$ phase

(インドメタシンによる細胞周期 $\mathrm{S}$ 期への導入減少による甲状腺髄䇐癌細胞の増殖抑制 効果)

（著者：友田智哲、Moatamed F、Naeim F、Hershman JM、菅原正博）

平成20年 Experimental Biology and Medicine 233巻 1433頁～1440頁 


\section{学 位 論 文 要 旨}

Indomethacin inhibits cell growth of medullary thyroid carcinoma by reducing cell cycle progression into $\mathrm{S}$ phase

(インドメタシンによる細胞周期 S 期への導入減少による甲状腺髄様癌細胞の増殖抑制効果)

\section{方 法}

Non selective COX inhibitorであるインドメタシンの髄様癌に対する増殖抑制効果を検 討した。実験には甲状腺髄様癌細胞株 TT cel1、HR0 85-1、DR0 81-1の3株と比較対象と して甲状腺未分化細胞 ARO cel1と甲状腺正常細胞としてprimary cultureによるpig thyroidを使用した。薬剤は、インドメタシン、multiple tyrosin kinase inhibitorであ る sunitinib、 indomethacin ester(COX-2 inhibitor)、Naproxen (COX-1、2 inhibitor) を使用した。細胞増殖抑制の程度は薬剂投与後のMTT assayにて解析した。癌増殖抑制効果 の素因に関しては、癌増殖に関与していると考えられているprostaglandin E2 (PGE2)の定 量、蛍光抗体法によるapoptosis assay ( caspase 3/7、8、9)、Propidium iodineによるDNA 染色による細胞周期の解析、western blot analysisにて細胞周期関連因子である phosphorylated retinoblastoma（pRB）、retinoblastomaの蛋白レベルの変化を検討した。

\section{結 果}

インドメタシンは $10 \mu \mathrm{M}$ 以上で、用量依存性にすべての甲状腺髄様癌細胞に対して増殖 抑制効果を認めた。これらのレベルはSunitinibの100-200 $\mu$ Mに相当する効果であった。 AR0 ce11、pig thyroid ce11では増殖抑制効果は認められなかった。PGE2 レベルは indometacin ester (COX-2 inhibitor)で最も低值であったが、増殖抑制効果は最も低かっ た。インドメタシン投与後では、細胞周期でS期の減少、G0-G1期の増加が確認されたが、 それ以外のindometasin-esterやNaproxenではその効果は認められなかった。また、G1期よ りS 期へ細胞周期を移行させるpRB蛋白がインドメタシン投与後では低下することが確認さ れた。Caspase 3/7、8、9はインドメタシン投与後でも優位な差をもって増加を認めなかっ た。 


\section{考 察}

甲状腺髄様癌に対する治療は現在のところ手術が第一選択肢とされており、遠隔転移巣 や手術不可能な部位の再発等に対しては有効な治療法がないのが実情である。最近欧米で は 様々なtyrosin kinase inhibitorによる髄様癌に対する治験が行われている。インドメ タシンは、tyrosin kinase inhibitorの一つであるsunitinibの治療レベルとほぼ同様の効 果が得られることが細胞レベルで確認された。インドメタシンの癌増殖抑制効果は従来癌 増殖に関与すると考えられているPGE2のレベルを下げることによると考えられていた。今 回の研究ではPGE2はCOX-2 inhibitorであるindomethsin ester投与後の群がインドメタシ ンに比較して優位に減少したが、細胞増殖抑制効果はインドメタシンの方が強かった。従 ってインドメタシンの増殖抑制効果はPGE2を減少させることによるのみではないことが示 唆された。細胞周期での検討ではインドメタシンのみが、pRBの減少によるcell cycle arrestを引き起こしたと考えられた。

\section{結 論}

今回の研究でインドメタシンに髄様癌の増殖抑制効果があることが示唆され、臨床応用 につながると考えられた。 